\title{
Effect of Headgroup Variation on the Self-assembly of Cationic Surfactants with Sulfonatocalix[6]arene
}

\author{
Véronique Wintgens, ${ }^{a}$ József G. Harangozó, ${ }^{b}$ Zsombor Miskolczy, ${ }^{\text {b }}$ Jean-Michel \\ Guigner, ${ }^{\mathrm{c}}$ Catherine Amiel, ${ }^{\mathrm{a}}$ László Biczók ${ }^{\mathrm{b}}$
}

anniversité Paris Est, ICMPE (UMR7182), CNRS, UPEC, F 94320 Thiais, France

${ }^{\mathrm{b}}$ Institute of Materials and Environmental Chemistry, Research Centre for Natural Sciences, Hungarian Academy of Sciences, P.O. Box 286, 1519 Budapest, Hungary

${ }^{\mathrm{c}}$ Institut de Minéralogie, de Physique des Matériaux et de Cosmochimie (IMPMC, Sorbonne Universités - UPMC Université Paris 06, UMR CNRS 7590, Muséum National d'Histoire Naturelle, Institut de Recherche pour le Développement UR 2064 Place Jussieu F-75005 Paris, France

\footnotetext{
* Corresponding author. Phone: (+36 1) 382-6614; E-mail: biczok.laszlo@ttk.mta.hu
} 


\begin{abstract}
The effect of headgroup variation on the association of supramolecular amphiphiles composed of 4-sulfonatocalix[6]arene (SCX6) and cationic surfactant possessing tetradecyl substituent was studied in aqueous solutions at $\mathrm{pH}$ 7. When the surfactant contained hydrophilic trimethylammonium, pyridinium, or 1-methylimidazolium headgroup, highly reversible temperature-responsive nanoparticle-supramolecular micelle transformation could be attained at appropriately chosen component mixing ratios and $\mathrm{NaCl}$ concentrations. In these cases, the substantial negative molar heat capacity change $\left(\Delta C_{p}\right)$ rendered nanoparticle formation strongly endothermic at low temperature, whereas the assembly to supramolecular micelle was always accompanied by enthalpy gain. The $\Delta C_{p}$ values became less negative when the charge density and the hydrophilic character of the surfactant headgroup diminished. The association of the more hydrophobic 6-methoxyquinolinium and quinolinium surfactants with SCX6 did not lead to supramolecular micelle formation because the self-assembly into nanoparticles was highly exothermic.
\end{abstract}

Key words: Nanoparticle, supramolecular amphiphile, self-assembly, macrocycle, surfactant 


\section{INTRODUCTION}

Understanding the relationship between the molecular structure of surfactants and the properties of their aggregates is of crucial importance for the prediction and rational design of physico-chemical parameters in a wide range of applications. The effect of headgroup alteration on the micellization of cationic surfactants has been extensively examined, ${ }^{1-6}$ but no systematic studies are available in the literature for supramolecular amphiphiles. These non-covalently bound associates are produced by self-assembly of hydrophobic and hydrophilic constituents. ${ }^{7-9}$ Macrocyclic cavitands are especially suitable building blocks for the construction of supramolecular amphiphiles with easily controlable properties and versatile structures. $^{10-12}$

The $\pi$-electron-rich apolar interior and the polyanionic character of 4sulfonatocalix[n]arenes (SCXn) promote the encapsulation of cationic and aromatic compounds in their cavity. ${ }^{13}$ The inclusion complexes of the homologue comprising four sulfonatophenol units (SCX4) usually assemble to supramolecular vesicles. ${ }^{14-17}$ Mixing 1pyrenemethylammonium and 4-sulfonatocalix[5]arene (SCX5) solutions resulted in unilamellar vesicles with temperature-controllable reversible association and dissociation behavior. ${ }^{18}$ When supramolecular vesicles were composed of SCX4 and 1-dodecyl-1'methyl-4,4'-bipyridinium, gradual disintegration into constituents was found with rising temperature but the particle size barely diminished. ${ }^{19}$ Reduction of the 4,4 '-bipyridinium moiety to radical cation decreased the particle diameter, whereas the supramolecular vesicles completely disappeared upon further reduction. The vesicles prepared from myristoylcholine and SCX4 could be disrupted by enzymatic cleavage of the amphiphilic component to myristic acid and choline. ${ }^{14}$ An amphiphilic anthracene derivative produced thermoresponsive spherical nanoparticles (NP) with a narrow size distribution in the presence of SCX4. ${ }^{20}$ The self-organization to these NPs significantly accelerated the 
photodecomposition. Both nanoparticle and vesicle formations were reported upon mixing chitosan, a biocompatible and biodegradable polysaccharide with SCXn in acidic solution and the produced species were capable of encapsulating pharmaceutically active compounds. $^{21-22}$

Alkyltrimethylammonium bromide surfactants readily formed complex with hexamethylated 4-sulfonatocalix[6]arene (HMSCX6) in which the cationic headgroup interacted with the oxygen atoms of the methoxy substituent of the macrocycle. ${ }^{23}$ Such $1: 1$ binding of dodecyltrimethylammonium $\left(\mathrm{C}_{12} \mathrm{TA}^{+}\right)$ion induced association to supramolecular micelle (SM) in much more dilute solutions than the critical micelle concentration $(\mathrm{cmc})$ of the free surfactant. ${ }^{24}$ The size and composition of SM scarcely changed as long as unbound HMSCX6 remained in the solution. ${ }^{25}$ The self-organization of fluorescent compounds and calixarene type of macrocyclic amphiphile was employed for the creation of color-tunable photoemitting nanomaterials. ${ }^{26-28}$ Pillar[5]arene functionalized with galactose and dodecyl groups produced vesicles in water, which slowly rearranged to nanotubes capable of agglutination of bacterial cells. ${ }^{29}$ The vesicles composed of another amphiphilic pillar[5]arene transformed to micelles upon $\mathrm{pH}$ diminution and self-assembled to microtubes after 4 months. ${ }^{30}$ The $\mathrm{pH}$ change in water by bubbling $\mathrm{CO}_{2}$ was exploited to design $\mathrm{CO}_{2^{-}}$ responsive supramolecular amphiphile from sodium dodecyl sulfate (SDS) and pillar[5]arene containing tertiary amine groups at the two rims. The protonated form of the host produced pseudorotaxane with SDS which associated into spherical bilayer vesicles. ${ }^{31}$

Host-guest complexation of 1-alkyl-3-methylimidazolium $\left(\mathrm{C}_{\mathrm{n}} \mathrm{mim}^{+}\right)$cations with SCXn facilitated the self-organization to SM or NP depending on the conditions and the structure of the interacting molecules when the aliphatic group contained $n=12,14$, or 16 carbon atoms. ${ }^{32-34}$ In the presence of $\mathrm{NaCl}$, highly reversible $\mathrm{SM}-\mathrm{NP}$ transformation was achieved by temperature alteration in a narrow range when the macrocycle composed of 6 or 
8 hydroxybenzenesulfonate moieties. The smaller and more rigid SCX4 generated only NP formation in a substantially exothermic process. ${ }^{33}$ We have revealed how the macrocycle size, ionic strength, temperature, mixing ratio of the components, and chain length of the alkyl substituent affect the diameter, morphology and thermodynamics of $\mathrm{C}_{\mathrm{n}} \mathrm{mim}^{+}-\mathrm{SCXn}$ aggregates. ${ }^{32-34}$ Now, we focus our attention to the effect of headgroup variation on the association of 4-sulfonatocalix[6]arene (SCX6) with tetradecyl type of cationic surfactants $\left(\mathrm{C}_{14} \mathrm{X}^{+}\right)$. Our main objective is to unravel whether stimuli-responsive NP-SM transition can be accomplished with various $\mathrm{C}_{14} \mathrm{X}^{+}-\mathrm{SCX} 6$ supramolecular amphiphiles and to uncover the impact of the properties of the headgroup on the thermodynamics of the association. The formulas of the employed surfactants and cavitand are presented in Scheme 1.<smiles>CCCCCCCCC</smiles>

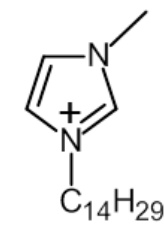

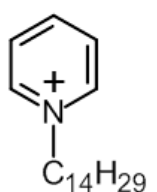

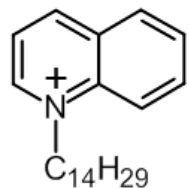

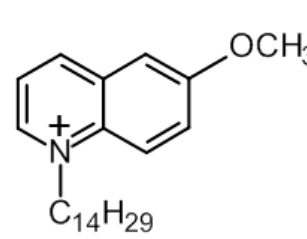

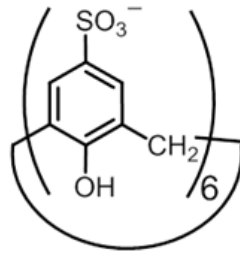

$\mathrm{C}_{14} \mathrm{TA}^{+} \quad \mathrm{C}_{14} \mathrm{mim}^{+}$<smiles></smiles><smiles>C[18OH]</smiles>

$\mathrm{C}_{14} \mathrm{MOQ}^{+}$

SCX6

\section{EXPERIMENTAL SECTION}

Materials. Tetradecyltrimethylammonium bromide $\left(\mathrm{C}_{14} \mathrm{TA}^{+} \mathrm{Br}^{-}\right)$(Fluka), 2-hydroxysubstituted nile red (HONR), also called 9-diethylamino-2-hydroxy-5H-benz[a]phenoxazin5-one (Aldrich) were used as received. 4-Sulfonato-calix[6]arene (SCX6) (TCI) was dried under vacuum at $333 \mathrm{~K}$ overnight. The water content of the latter compound was determined by total organic carbon analysis. N-tetradecylpyridinium bromide ${ }^{35}\left(\mathrm{C}_{14} \mathrm{Py}^{+} \mathrm{Br}^{-}\right)$was prepared as reported. The synthesis of $\mathrm{N}$-tetradecylquinolinium bromide $\left(\mathrm{C}_{14} \mathrm{Q}^{+} \mathrm{Br}^{-}\right)$and $\mathrm{N}$ tetradecyl-6-methoxyquinolinium bromide $\left(\mathrm{C}_{14} \mathrm{MOQ}^{+} \mathrm{Br}^{-}\right)$are described in Supporting Information. 
Sample preparation. NPs were prepared by mixing the appropriate amounts of surfactant solutions under stirring at $150 \mathrm{rpm}$ at $25^{\circ} \mathrm{C}$. SCX6 concentration was $0.1 \mathrm{mM}$ unless otherwise stated. Ionic strength was adjusted by $2.5 \mathrm{M} \mathrm{NaCl}$ stock solution.

Stoichiometry of the components in the NPs. NPs were separated from the liquid phase by a Beckman Coulter (Optima Max-XP, type TLA 110 rotor) ultracentrifuge. SCX6 or C14MOQ concentrations in the supernatants were determined by spectrophotometric method, whereas total organic content (TOC) analysis provided information on the sum of the concentrations of SCX6 and surfactant. The amounts of the components in NPs were obtained as a difference of total and solved quantities. Further details have been reported. ${ }^{34}$ Application of fluorescent probe. $23 \mathrm{nmol} \mathrm{HONR}$ in methanol was put into $5 \mathrm{ml}$ flask and the solvent was evaporated by letting nitrogen flow over the solution. After adding the supramolecular surfactant solution, the sample was kept for 2 days in the dark for equilibration.

Instrumentation. Corrected fluorescence spectra were recorded on a Jobin-Yvon Fluoromax-P photon-counting spectrofluorometer. Particle size and zeta potential were measured on a Zetasizer Nano-ZS (Malvern Instrument). The mean diameter of the NPs was derived on the basis of number distribution. The mean error of the particle sizes determined by dynamic light scattering is $\sim 15 \%$ (average of at least 3 different experiments). Total carbon analyses were carried out on a Shimadzu TOC-L CSN instrument, which was calibrated by a potassium hydrogen phthalate solution in ultrapure water $\left(2.125 \mathrm{~g} \mathrm{dm}^{-3}\right.$ corresponding to $1000 \mathrm{mgC} \mathrm{dm}^{-3}$ ). Isothermal titration calorimetry (ITC) measurements were performed with a MicroCal VP-ITC microcalorimeter. $10 \mu \mathrm{l}$ of surfactant solutions were injected from the computer controlled microsyringe into the cell containing $0.1 \mathrm{mM}$ SCX6 solution at $\mathrm{pH} 7$, while stirring at $450 \mathrm{rpm}$. The dilution heat was always subtracted. Cryo-transmission electron microscopy (TEM) images were taken on an Ultrascan 2K CCD 
camera (Gatan, USA), using LaB6 JEOL JEM 2100 (JEOL, Japan) cryo-microscope as previously described. ${ }^{34}$

\section{RESULTS}

3.1. Micelle Formation of Surfactants. The critical micelle concentration $(\mathrm{cmc})$ and thermodynamic parameters of association into micelles for various amphiphiles possessing tetradecyl moiety $\left(\mathrm{C}_{14} \mathrm{X}^{+} \mathrm{Br}^{-}\right)$were determined by isothermal calorimetric titrations. Micelle solutions were injected into the corresponding solvent and the $\mathrm{cmc}$ values were obtained from the maximum of the first derivative of the enthalpograms, which corresponds to the inflection point. The experimental results obtained at $298 \mathrm{~K}$ are summarized in Table 1, whereas Figure $\mathrm{S} 1$ presents the small change of cmc values with temperature. The charge distribution of the

Table 1 Headgroup properties, cmc values and thermodynamic parameters of micelle formation at $298 \mathrm{~K}$ in water and $50 \mathrm{mM} \mathrm{NaCl}$ aqueous solution

\begin{tabular}{|c|c|c|c|c|c|c|}
\hline & $\begin{array}{c}\mathrm{NaCl}] \\
/ \mathrm{mM}\end{array}$ & $\mathrm{C}_{14} \mathrm{TA}^{+} \mathrm{Br}^{-}$ & $\mathrm{C}_{14} \mathrm{mim}^{+} \mathrm{Br}^{-}$ & $\mathrm{C}_{14} \mathrm{Py}^{+} \mathrm{Br}^{-}$ & $\mathrm{C}_{14} \mathrm{Q}^{+} \mathrm{Br}^{-}$ & $\mathrm{C}_{14} \mathrm{MOQ}^{+} \mathrm{Br}^{-}$ \\
\hline $\begin{array}{l}\text { Headgroup } \\
\text { charge per } \\
\text { volume / } \\
\text { electron } \mathrm{nm}^{-3}\end{array}$ & & 6.48 & 5.61 & 6.33 & 3.74 & 2.89 \\
\hline $\begin{array}{l}\text { Headgroup } \\
\log P\end{array}$ & & -0.56 & 0.43 & 1.39 & 2.16 & 1.91 \\
\hline \multirow{2}{*}{$\begin{array}{l}\mathrm{cmc}(298 \mathrm{~K}) / \\
\mathrm{mM}\end{array}$} & 0 & 3.73 & 2.56 & 2.89 & 1.11 & 0.66 \\
\hline & 50 & 1.25 & 0.72 & 0.75 & 0.24 & 0.12 \\
\hline \multirow{2}{*}{$\begin{array}{l}\Delta H(298 \mathrm{~K}) / \\
\mathrm{kJ} \mathrm{mol}^{-1}\end{array}$} & 0 & -5.0 & -6.1 & -6.5 & -7.5 & -11.9 \\
\hline & 50 & -0.61 & $-2.0^{\mathrm{a}}$ & -1.3 & -2.7 & -5.9 \\
\hline \multirow{2}{*}{$\begin{array}{l}\Delta C_{p} / \\
\mathrm{kJ} \mathrm{mol}^{-1} \mathrm{~K}^{-1}\end{array}$} & 0 & -0.52 & $-0.595^{b}$ & -0.47 & -0.60 & -0.60 \\
\hline & 50 & -0.52 & $-0.54^{\mathrm{a}}$ & -0.46 & -0.50 & -0.45 \\
\hline \multirow{2}{*}{$\begin{array}{l}\text { Intercept / } \\
\mathrm{kJ} \mathrm{mol}^{-1}\end{array}$} & 0 & 150 & & 135 & 171 & 166 \\
\hline & 50 & 155 & $160^{\mathrm{a}}$ & 135 & 146 & 129 \\
\hline \multirow{2}{*}{$T_{i e} / \mathrm{K}$} & 0 & 288 & & 286 & 285 & 277 \\
\hline & 50 & 298 & 296 & 293 & 292 & 287 \\
\hline
\end{tabular}

${ }^{\mathrm{a}} \operatorname{Ref}^{32-33}$, ${ }^{\mathrm{b}}$ for $\mathrm{C}_{14} \mathrm{mim}^{+} \mathrm{Cl}^{-} \operatorname{Ref}^{36}$ 
surfactants, headgroup van der Waals volume and logarithm of the partition coefficient between $n$-octanol and water $(\log \mathrm{P})$ of the headgroup were calculated by HyperChem 8.0.10 software as described in Supporting Information. The headgroup charge per van der Waals volume was used to characterize the charge density on the cationic group of surfactant, whereas increase of $\log \mathrm{P}$ parameter indicated the rise of its hydrophobicity. A correlation was found between the cmc values and the charge density of the cationic moiety of surfactants indicating that the diminution of the electrostatic repulsion among the headgroups facilitates the association into micelles. The addition of $50 \mathrm{mM} \mathrm{NaCl}$ brought about considerable $\mathrm{cmc}$ lessening due to the effective screening of the electrostatic interaction among the headgroups within the micelle. The enthalpy change upon micelle formation $(\Delta H)$, which was determined as described by Blume and coworkers, ${ }^{37}$ significantly decreased in the series of $\mathrm{C}_{14} \mathrm{TA}^{+} \mathrm{Br}^{-}>$ $\mathrm{C}_{14} \mathrm{mim}^{+} \mathrm{Br}^{-}>\mathrm{C}_{14} \mathrm{Py}^{+} \mathrm{Br}^{-}>\mathrm{C}_{14} \mathrm{Q}^{+} \mathrm{Br}^{-}>\mathrm{C}_{14} \mathrm{MOQ}^{+} \mathrm{Br}^{-}$. This trend resembles the diminution of the headgroup charge per volume of the cationic headgroup. The slope of the linear correlation between $\Delta H$ and temperature $(T)$ provided the molar heat capacity change $\left(\Delta C_{p}\right)$. The isoenthalpic temperature $\left(T_{i e}\right)$, where $\Delta H=0 \mathrm{~kJ} \mathrm{~mol}^{-1}$, was calculated using the slope and the intercept (Int) of $\Delta H$ vs. $T$ relationship as follows: $T_{i e}=-I n t / \Delta C_{p}$. Micelle formation was always exothermic above $298 \mathrm{~K}$. The variation of $\Delta C_{p}$ and $I n t$ was less than $25 \%$ in the series of surfactants and did not exhibit a trend. This indicates that the alteration of the water structure around the tetradecyl substituent is the dominant factor affecting $\Delta C_{p}$, whereas the changes in hydration and interactions for the cationic headgroup have a smaller contribution. $\Delta C_{p}$ found in the present study for $\mathrm{C}_{14} \mathrm{TA}^{+} \mathrm{Br}^{-}$agrees within the limits of experimental errors with that $\left(-0.499 \mathrm{~kJ} \mathrm{~mol}^{-1} \mathrm{~K}^{-1}\right)$ reported by Bashford and Woolley. ${ }^{38}$

3.2. SCX6-induced Nanoparticle Formation in Water. Particle formation started in aqueous solution at pH 7 immediately after mixing $\mathrm{C}_{14} \mathrm{X}^{+} \mathrm{Br}^{-}$and SCX6 at equimolar ratio. 
Nanoparticles (NPs) were investigated at various mixing ratio $(r)$. At a specific mixing ratio, NPs became unstable and coalesced due to the compensation of the positive charges of the surfactants cationic headgroup by the negative charges of SCX6. At neutral pH, SCX6 had 8 negative charges. Not only the six sulfonate groups were deprotonated but also two phenolic $\mathrm{OH}$ substituents dissociated because their pKa values were 3.29 and 4.91 in $0.1 \mathrm{M} \mathrm{NaCl}$ solution at $298 \mathrm{~K}^{39}$ The mixing ratio where NP destabilization began $\left(r_{\text {limit }}\right)$ slightly diminished in the series of $\mathrm{C}_{14} \mathrm{TA}^{+} \mathrm{Br}^{-}\left(r_{\text {limit }}=8.5\right)>\mathrm{C}_{14} \mathrm{Py}^{+} \mathrm{Br}^{-} \sim \mathrm{C}_{14} \mathrm{mim}^{+} \mathrm{Br}^{-}\left(r_{\text {limit }}=8\right)>$ $\mathrm{C}_{14} \mathrm{Q}^{+} \mathrm{Br}^{-} \sim \mathrm{C}_{14} \mathrm{MOQ}^{+} \mathrm{Br}\left(r_{\text {limit }}=7\right)$.

Among the various studied surfactants, $\mathrm{C}_{14} \mathrm{TA}^{+} \mathrm{Br}^{-}$produced the least stable NPs over one day. In the case of this surfactant, NPs were stable over one day only at molar ratio of $6 \leq$ $r \leq 7$. These NPs had mean diameter of $d=92 \mathrm{~nm}$ (mean polydispersity index PDI $\sim 0.1$ ) and negative zeta potential $(\sim-22 \mathrm{mV}$ at $r=7)$, at $298 \mathrm{~K}$. At $1 \leq r \leq 6$, NP diameter substantially increased with time. Figure S2 presents the average of the results of three experiments as a function of $r$. For example, the diameter of NPs increased within one day from $45 \mathrm{~nm}$ to 105 $\mathrm{nm}$ for $r=4$, and from $20 \mathrm{~nm}$ to $120 \mathrm{~nm}$ for $r=2$. More stable NPs were produced when $\mathrm{C}_{14} \mathrm{Py}^{+} \mathrm{Br}^{-}$was used. The mean diameter of these NPs scarcely varied within one day, but increased from $30 \mathrm{~nm}$ to $95 \mathrm{~nm}$ (mean PDI 0.1) when the $\left[\mathrm{C}_{14} \mathrm{Py}^{+} \mathrm{Br}^{-}\right] /[\mathrm{SCX} 6]$ mixing ratio was raised from 2 to 7 (Figure 1A). In the $2<r<6$ domain, the negative zeta potential slightly grew from $-30 \mathrm{mV}$ to $-25 \mathrm{mV}$, but then increased steeply until the vanishing surface charge led to destabilization (Figure 1B). The SCX6-initiated NP formation of $\mathrm{C}_{14} \mathrm{Py}^{+} \mathrm{Br}^{-}$closely resembled that reported for $\mathrm{C}_{14} \mathrm{mim}^{+} \mathrm{Br}^{-}$in our previous paper. ${ }^{34}$ The mean diameter of NPs comprising $\mathrm{C}_{14} \mathrm{Q}^{+}$and $\mathrm{C}_{14} \mathrm{MOQ}^{+}$slowly grew until reaching a constant value in $\sim 7$ h. As seen in Figure S3, the NP size also increased with the growth of the surfactant excess. After stabilization time, NP diameters varied within the $2<r<6$ mixing ratio range 


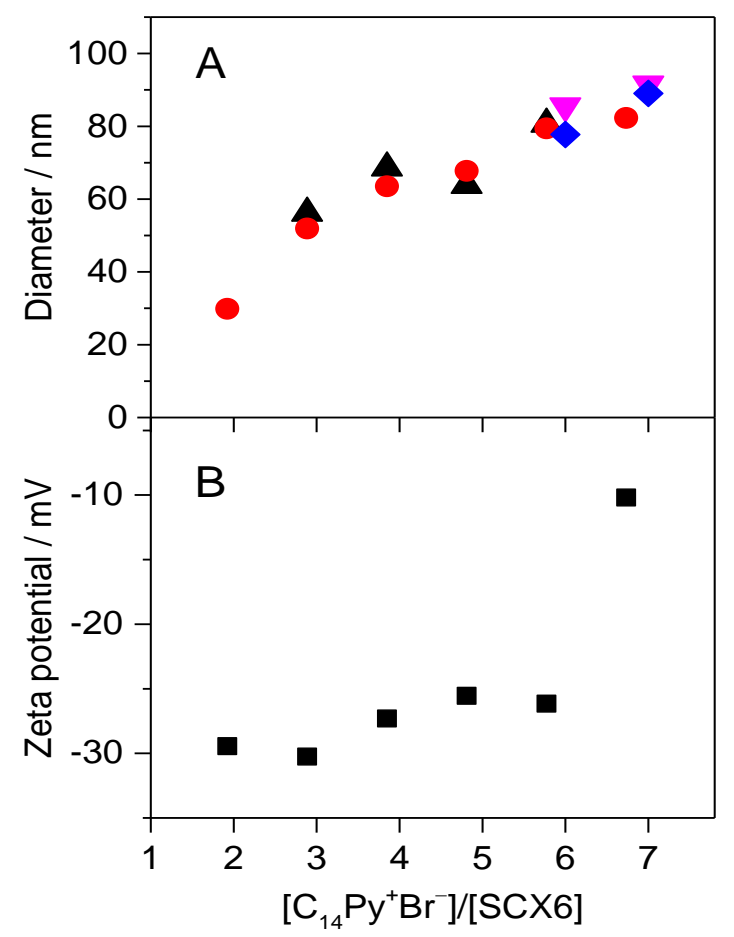

Figure 1 (A) Mean diameter of nanoparticles at $1(\diamond), 2(\bullet), 7(\boldsymbol{\nabla}) \mathrm{h}$ after mixing $\mathrm{C}_{14} \mathrm{Py}^{+} \mathrm{Br}^{-}$ and SCX6 solutions in various ratios at $298 \mathrm{~K}$. Average of the diameters measured at 0,2 , and $24 \mathrm{~h}$ after mixing ( $\mathbf{\Delta})[\mathrm{SCX} 6]=0.1 \mathrm{mM}$. (B) Zeta potentials as a function of $\left[\mathrm{C}_{14} \mathrm{Py}^{+} \mathrm{Br}^{-}\right] /[\mathrm{SCX} 6]$ mixing ratio.

from $39 \mathrm{~nm}$ to $78 \mathrm{~nm}$ for $\mathrm{C}_{14} \mathrm{Q}^{+}-\mathrm{SCX} 6$, whereas an increase from $50 \mathrm{~nm}$ to $82 \mathrm{~nm}$ was observed for $\mathrm{C}_{14} \mathrm{MOQ}^{+}-\mathrm{SCX} 6$. The mean PDI was always $\sim 0.1$. Zeta potentials at $\mathrm{r}=6$ were around $-32 \mathrm{mV}$ and $-22 \mathrm{mV}$ for $\mathrm{C}_{14} \mathrm{Q}^{+}-\mathrm{SCX} 6$ and $\mathrm{C}_{14} \mathrm{MOQ}^{+}-\mathrm{SCX} 6$, respectively.

The stoichiometry of NPs was determined from the difference between the total concentrations and the concentrations in the aqueous phase after ultracentrifugation of the NPs, as previously reported. ${ }^{34}$ The mean values of the results, obtained using at least three different mixing ratios for each surfactant, are summarized in Table 2. The stoichiometry was always close to the charge neutralization but the volume of the cationic headgroup had a slight influence. The lowest surfactant:SCX6 molar ratio in NPs and the highest zeta 
potential were found when the surfactant contained the most spacious 6-methoxyquinolinium moiety (Table 2).

Table 2 Zeta potentials, mean values of surfactant cation/SCX6 molar ratios in nanoparticles at $298 \mathrm{~K}$ and the calculated volume of the headgroup

\begin{tabular}{|l|c|c|c|c|c|}
\hline Surfactant & $\mathrm{C}_{14} \mathrm{TA}^{+} \mathrm{Br}^{-}$ & $\mathrm{C}_{14} \mathrm{mim}^{+} \mathrm{Br}^{-}$ & $\mathrm{C}_{14} \mathrm{Py}^{+} \mathrm{Br}^{-}$ & $\mathrm{C}_{14} \mathrm{Q}^{+} \mathrm{Br}^{-}$ & $\mathrm{C}_{14} \mathrm{MOQ}^{+} \mathrm{Br}^{-}$ \\
\hline $\begin{array}{l}\text { Zeta potential } \\
\text { at } \mathrm{r}=6\end{array}$ & -34 & -35 & -35 & -32 & -22 \\
\hline NP stoichiometry & 7.5 & 7.4 & 7.7 & 7.2 & 6.6 \\
\hline $\begin{array}{l}\text { Headgroup van der } \\
\text { Waals volume / nm }\end{array}$ & 0.108 & 0.115 & 0.105 & 0.180 & 0.235 \\
\hline
\end{tabular}

${ }^{\mathrm{a}}$ average of the results of three independent measurements

3.3. Morphology of Nanoparticles. Cryo-TEM measurements allow the observation of particles in their aqueous environment. It is important to preserve the sample in a frozen hydrated state because dehydration may induce structural change. To gain information about the shape and internal structure of NPs, cryo-TEM images were recorded one hour after mixing the components at $298 \mathrm{~K}$. Representative results are presented in Figure 2. SCX6 concentration of $0.2 \mathrm{mM}$ was employed and the surfactants had 6- or 7-fold molar excess relative to $\mathrm{SCX} 6 . \mathrm{C}_{14} \mathrm{TA}^{+}-\mathrm{SCX} 6$ particles were less stable under electron beam irradiation than the NPs of other surfactants. Spherical external appearance was found for the small $\mathrm{C}_{14} \mathrm{TA}^{+}-\mathrm{SCX} 6$ particles, whereas the larger aggregates exhibited ellipsoid shape (Figure 2A). Parallel lines about $3.5 \mathrm{~nm}$ apart were observed in the core of $\mathrm{C}_{14} \mathrm{Py}^{+}-\mathrm{SCX} 6 \mathrm{NPs}$ (Figure 2B) indicating lamellar inner structure similar to that reported for $\mathrm{C}_{14} \mathrm{mim}^{+}-\mathrm{SCX} 6 \mathrm{NPs}{ }^{32}$ The majority of $\mathrm{C}_{14} \mathrm{Py}^{+}-\mathrm{SCX} 6$ NPs were spherical but about one third of them showed slightly oblate spheroid contour. In contrast, spherical NPs were detected for both $\mathrm{C}_{14} \mathrm{Q}^{+}-\mathrm{SCX} 6$ and 

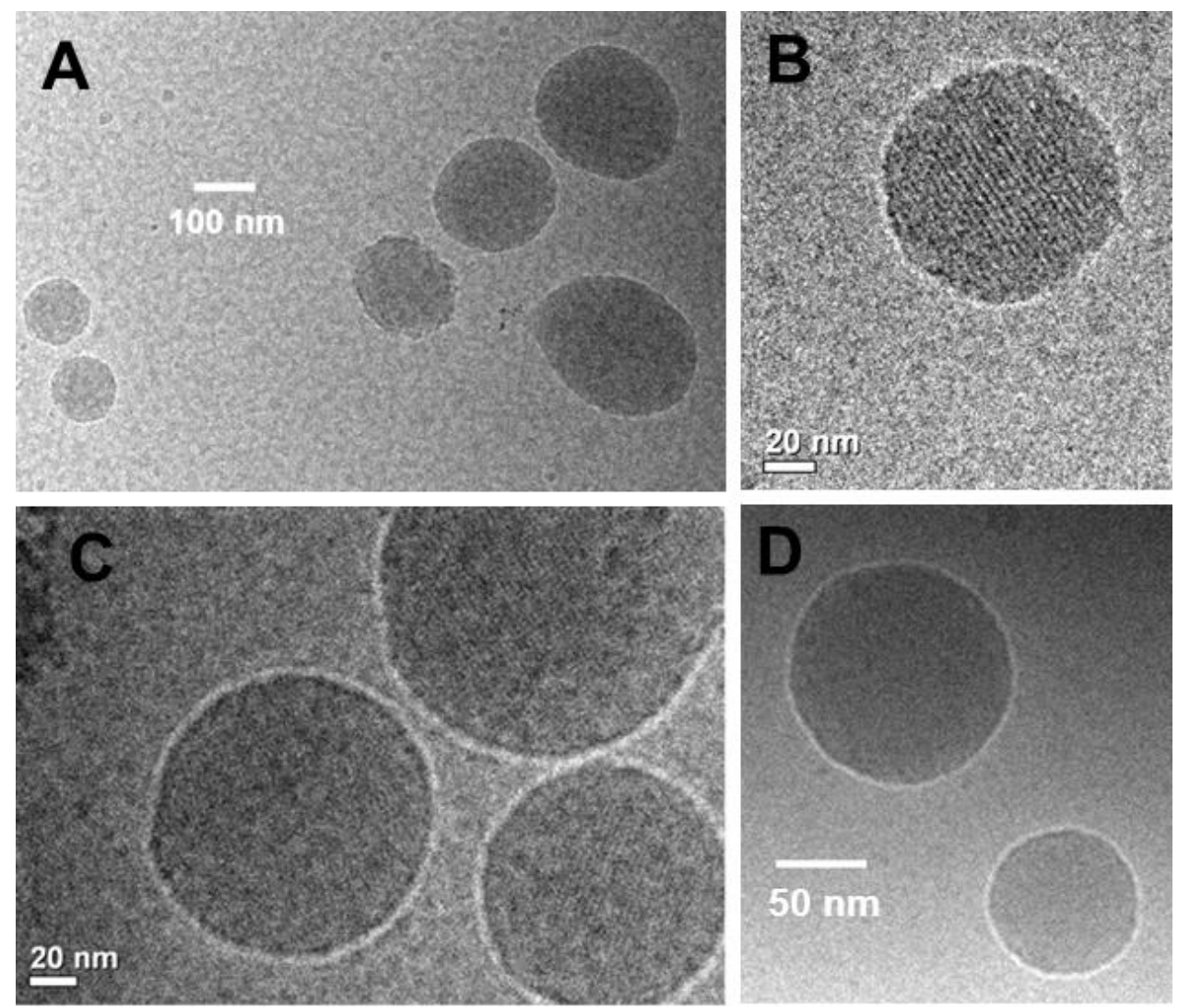

Figure 2 Cryo-TEM images for (A) $\mathrm{C}_{14} \mathrm{TA}^{+}-\mathrm{SCX} 6$ solution of molar ratio $r=7$, (B) $\mathrm{C}_{14} \mathrm{Py}^{+}-\mathrm{SCX} 6$ solution of molar ratio $r=6$, (C) $\mathrm{C}_{14} \mathrm{Q}^{+}-\mathrm{SCX} 6$ solution of molar ratio $r=6$, and (D) $\mathrm{C}_{14} \mathrm{MOQ}^{+}-\mathrm{SCX} 6$ solution of molar ratio $r=6$. The solutions were equilibrated at 298 $\mathrm{K}$ for one hour before recording images. $[\mathrm{SCX} 6]=0.2 \mathrm{mM}$.

$\mathrm{C}_{14} \mathrm{MOQ}^{+}-\mathrm{SCX} 6$, but lamellar arrangement with a repeat spacing of $\sim 2.5 \mathrm{~nm}$ appeared only in the former case (Figure 2C). The lack of pattern in $\mathrm{C}_{14} \mathrm{MOQ}^{+}-\mathrm{SCX} 6$ NPs (Figure 2D) arises probably from steric reasons. The methoxy substituents may partly hinder the $\pi-\pi$ interaction among the quinolinium rings.

3.4. Effect of $\mathrm{NaCl}$ Concentration. Figure 3 presents how the gradual addition of $\mathrm{NaCl}$ affects the size of $\mathrm{C}_{14} \mathrm{TA}^{+}-\mathrm{SCX} 6$ associates at $298 \mathrm{~K}$. Substantial diameter growth was found in the $4 \leq r \leq 7$ domain. The NPs were coagulated when the amount of $\mathrm{NaCl}$ reached 100 

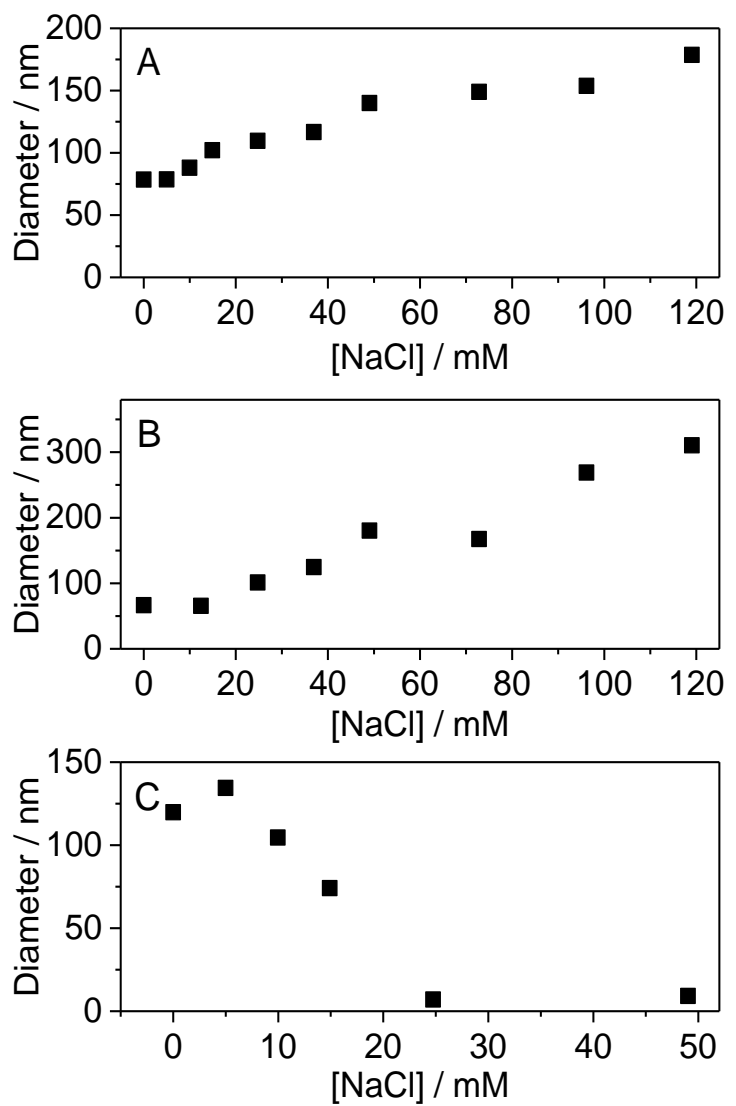

Figure 3 Effect of $\mathrm{NaCl}$ concentration on the particle mean diameter for $\mathrm{C}_{14} \mathrm{TA}^{+} \mathrm{Br}^{-}: \mathrm{SCX} 6$ solution of molar ratio (A) 6, (B) 4, and (C) 2 at $298 \mathrm{~K}$. The NP solutions were equilibrated (A) 4.5, (B) 7, and (C) $28 \mathrm{~h}$ before the titrations. DLS measurements were performed $2 \mathrm{~min}$ after each successive $\mathrm{NaCl}$ addition. $[\mathrm{SCX} 6]=0.1 \mathrm{mM}$.

$\mathrm{mM}$ at $r=7$ or $150 \mathrm{mM}$ at $r=6$ but such a change did not take place at lower component mixing ratios. At twofold molar excess of $\mathrm{C}_{14} \mathrm{TA}^{+} \mathrm{Br}^{-}$relative to SCX6, particles of $\sim 7-9 \mathrm{~nm}$ mean diameter were found at $[\mathrm{NaCl}] \geq 25 \mathrm{mM}$. This structure alteration resembled that reported for $\mathrm{C}_{14} \mathrm{mim}^{+}-\mathrm{SCX} 6 \mathrm{NPs}^{32}$ and assigned to supramolecular micelle (SM) formation. The salt-promoted reassembly of $\mathrm{C}_{14} \mathrm{TA}^{+}$and SCX6 to SM was less abrupt than for $\mathrm{C}_{14} \mathrm{mim}^{+}-\mathrm{SCX} 6$ NPs and occurred at higher salt concentration. Both the size and the inner structure of SMs basically differ from those of NPs. In the much smaller SMs, only the apolar aliphatic chains are located in the core of the particles and the SCX6 macrocycles are 
bound to the cationic headgroups at the surface in contact with surrounding water. In contrast, the inner part of NPs is composed of $\left(\mathrm{C}_{14} \mathrm{mim}^{+}\right)_{\mathrm{n}}-\mathrm{SCX} 6$ units $(\mathrm{n}=7-8)$.

$\mathrm{NaCl}$ addition was unable to induce the rearrangement of $\mathrm{C}_{14} \mathrm{Py}^{+}-\mathrm{SCX} 6$, $\mathrm{C}_{14} \mathrm{Q}^{+}-\mathrm{SCX} 6$, or $\mathrm{C}_{14} \mathrm{MOQ}^{+}-\mathrm{SCX} 6 \mathrm{NPs}$ to $\mathrm{SM}$ at any mixing ratios at $298 \mathrm{~K}$. The gradual increase of $\mathrm{NaCl}$ amount brought about an initial NP growth, but the size leveled off above $\sim 50 \mathrm{mM} \mathrm{NaCl}$ concentration reaching $\sim 125 \mathrm{~nm}$ and $\sim 185 \mathrm{~nm}$ mean diameters in the case of quinolinium type of surfactants and $\mathrm{C}_{14} \mathrm{Py}^{+}$, respectively (Figure 4). These NPs are quite stable in the presence of salt. No size change was observed after one day.

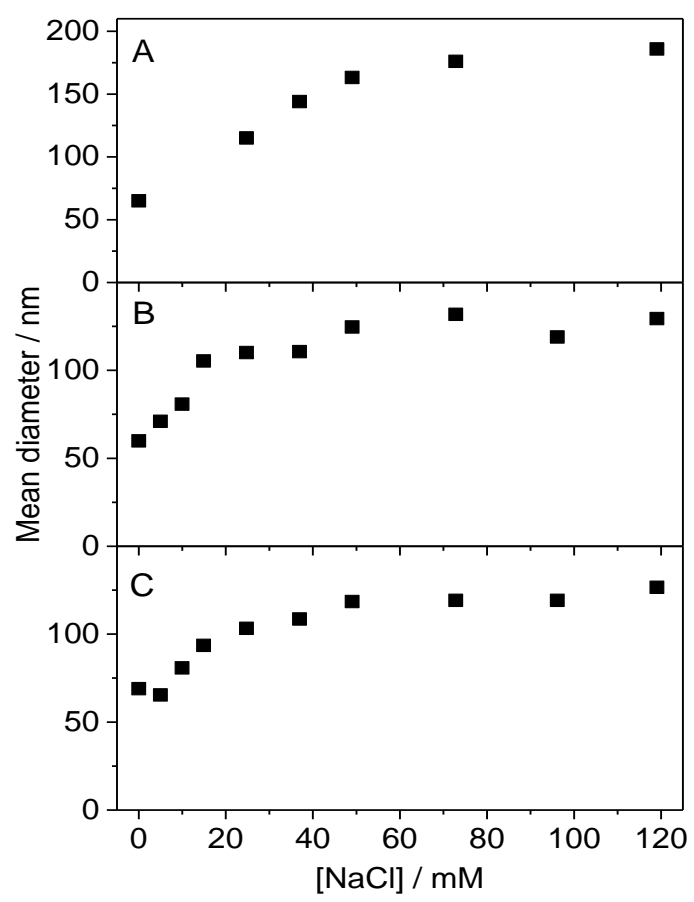

Figure 4 Mean diameter of (A) $\mathrm{C}_{14} \mathrm{Py}^{+}-\mathrm{SCX} 6$, (B) $\mathrm{C}_{14} \mathrm{Q}^{+}-\mathrm{SCX} 6$ and (C) $\mathrm{C}_{14} \mathrm{MOQ}^{+}-\mathrm{SCX} 6$ NPs produced at $r=4$ mixing ratio as a function of $\mathrm{NaCl}$ concentration at $298 \mathrm{~K}$. NP solutions were equilibrated for $7 \mathrm{~h}$. DLS measurements were performed 2 min after each successive $\mathrm{NaCl}$ addition. $[\mathrm{SCX} 6]=0.1 \mathrm{mM}$.

3.5. Effect of Temperature Variation. The cooling of $\mathrm{C}_{14} \mathrm{Py}^{+}-\mathrm{SCX} 6 \mathrm{NPs}$ in $50 \mathrm{mM} \mathrm{NaCl}$ solution to $288 \mathrm{~K}$ or below this temperature led to transition from NP of $250 \pm 10 \mathrm{~nm}$ to SM 
of $4.8 \pm 0.4 \mathrm{~nm}$ mean diameters at $r=3$ mixing ratio. In contrast, no SM formation was attained at $r>4$. The repeated cooling and heating cycles provided highly reversible NP-SM transitions with reproducible particle sizes (Figure 5). Similar results were obtained for

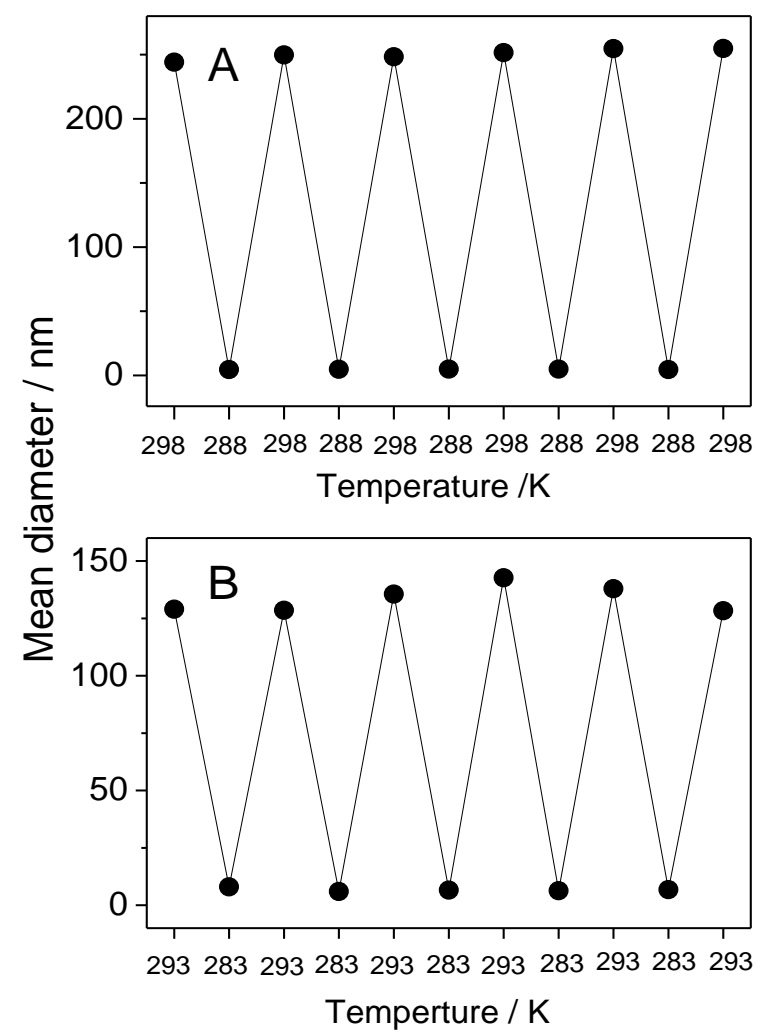

Figure 5 Particle size alteration measured by dynamic light scattering (A) at $r=3$ for $\mathrm{C}_{14} \mathrm{Py}^{+}-\mathrm{SCX} 6$ in $50 \mathrm{mM} \mathrm{NaCl}$ solution and (B) at $r=4$ for $\mathrm{C}_{14} \mathrm{TA}^{+}-\mathrm{SCX} 6$ in $15 \mathrm{mM} \mathrm{NaCl}$ solution 25 min after repeated temperature change.

$\mathrm{C}_{14} \mathrm{TA}^{+}$-SCX6. In this case, $15 \mathrm{mM} \mathrm{NaCl}$ concentration was sufficient for the temperatureinduced NP-SM interconversion, but this structure change did not occur at $r>4$. Figure 5B shows that the structure switch from NPs of $136 \pm 6 \mathrm{~nm}$ to SMs of $6.8 \pm 0.5 \mathrm{~nm}$ mean diameter was achieved upon temperature alteration between 293 and $283 \mathrm{~K}$ at $r=4$. Representative size distributions obtained by dynamic light scattering method are presented in Figure S4. The tuning of the mixing ratio of the components to $r=3$ shifted the thermalinitiated size change to the $298-288 \mathrm{~K}$ range. Temperature alteration did not induce the 
conversion of $\mathrm{C}_{14} \mathrm{Q}^{+}-\mathrm{SCX} 6$ and $\mathrm{C}_{14} \mathrm{MOQ}^{+}-\mathrm{SCX} 6 \mathrm{NPs}$ to SMs under any the experimental conditions.

3.6. Isothermal Titration Calorimetry. ITC experiments provided insight into the thermodynamic origin of the differences in the association characteristics of the various supramolecular amphiphiles. $\mathrm{C}_{14} \mathrm{X}^{+} \mathrm{Br}^{-}$solution with $50 \mathrm{mM} \mathrm{NaCl}$ was added to $0.1 \mathrm{mM}$ SCX6 and $50 \mathrm{mM} \mathrm{NaCl}$ mixture at $\mathrm{pH}$ 7. The dilution heat of the titrant, determined by the titration of $50 \mathrm{mM} \mathrm{NaCl}$, was always subtracted. Because of their low cmc, the quinolinium surfactants were injected into $0.02 \mathrm{mM}$ SCX6 solution. The other $\mathrm{C}_{14} \mathrm{X}^{+} \mathrm{Br}^{-}$compounds were added to $0.1 \mathrm{mM}$ SCX6 solution. As a representative example, Figure 6 displays the enthalpograms for the titration with $\mathrm{C}_{14} \mathrm{TA}^{+} \mathrm{Br}^{-}$. At $278 \mathrm{~K}$, the rise of $\Delta H$ values in the $r=\left[\mathrm{C}_{14} \mathrm{TA}^{+}\right] /[\mathrm{SCX} 6]<0.7$ mixing ratios is assigned to association of several $\mathrm{C}_{14} \mathrm{TA}^{+}$cations to the polyanionic SCX6. The gradual increase of the number of complexed surfactant ions is

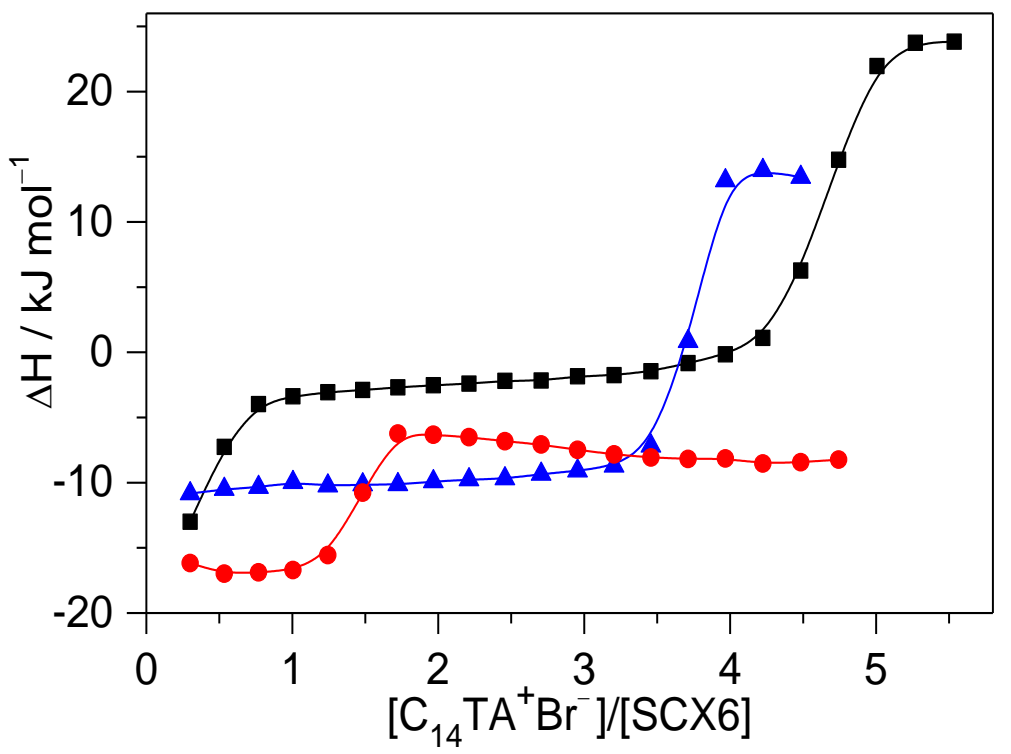

Figure 6 Results of ITC measurements at $298(\bullet), 288(\boldsymbol{\Delta})$, and $278 \mathrm{~K}(\boldsymbol{\nabla})$ in $50 \mathrm{mM} \mathrm{NaCl}$ solutions after correction with dilution heat; 0.1 mM SCX6 solution was titrated with $3.0 \mathrm{mM}$ $\mathrm{C}_{14} \mathrm{TA}^{+} \mathrm{Br}^{-}$at $\mathrm{pH} 7$ keeping $50 \mathrm{mM} \mathrm{NaCl}$ concentration constant. 
accompanied by diminishing exothermicity of the binding steps. When the amount of $\left(\mathrm{C}_{14} \mathrm{TA}^{+}\right)_{\mathrm{n}}-\mathrm{SCX} 6$ complexes exceeds the critical association concentration, self-organization into SM takes place. In the $0.7<r<4$ domain, $\Delta H$ barely alters because only the number of SMs increases; their size remains practically constant. Further increase of the relative amount of $\mathrm{C}_{14} \mathrm{TA}^{+}$leads to gradual transformation of SMs to NPs. Since the association into NP is an endothermic process at low temperature, $\Delta H$ significantly grows in the $4.2<r<5.2$ range. A plateau is reached at mixing ratios where merely NP exists. When temperature is raised, $\Delta H$ for NP formation diminishes to a larger extent than that for the assembly into SM and the SM-NP transition occurs at considerably smaller $r$ values. The endothermic assembly into NPs turns to exothermic at $298 \mathrm{~K}$ facilitating thereby NP formation. The results of isothermal calorimetric titrations of SCX6 with $\mathrm{C}_{14} \mathrm{TA}^{+} \mathrm{Br}^{-}$solution resemble those found for the associations leading to $\mathrm{C}_{14} \mathrm{Py}^{+}-\mathrm{SCX} 6$ (Figure S5) and $\mathrm{C}_{14} \mathrm{mim}^{+}-\mathrm{SCX} 6 .{ }^{32}$ When $\mathrm{C}_{14} \mathrm{Q}^{+}$or $\mathrm{C}_{14} \mathrm{MOQ}^{+}$solutions served as titrant, practically constant heat evolution was obtained due to the association with SCX6 into NPs as long as no coagulation occurred. $\Delta H$ remained negative at all temperatures.

The experiments repeated at various temperatures provided linear correlations between the enthalpy change $(\Delta H)$ and temperature $(T)$ for both the NP and SM formations. The temperature dependences of $\Delta H$ for the various self-assemblies are presented in Figure 7 . The intercepts $($ Int $)$ and the molar heat capacity changes $\left(\Delta C_{p}\right)$ derived from the slopes are listed in Table 3. The SCX6-initiated self-organization to SM is exothermic at all temperatures in 50 $\mathrm{mM} \mathrm{NaCl}$ solution and $\Delta H \mathrm{~s}$ are very similar for all surfactants. The Int and $\Delta C_{p}$ values of SM production barely differ for $\mathrm{Py}^{+}$and $\mathrm{C}_{14} \mathrm{mim}^{+}$but somewhat larger Int and more negative $\Delta C_{p}$ are found for $\mathrm{C}_{14} \mathrm{TA}^{+}$. The Int quantities of NP production diminish in the sequence of $\mathrm{C}_{14} \mathrm{TA}^{+}-\mathrm{SCX} 6>\mathrm{C}_{14} \mathrm{mim}^{+}-\mathrm{SCX} 6>\mathrm{C}_{14} \mathrm{Py}^{+}-\mathrm{SCX} 6$ whereas the $\Delta C_{p}$ data exhibit an opposite 

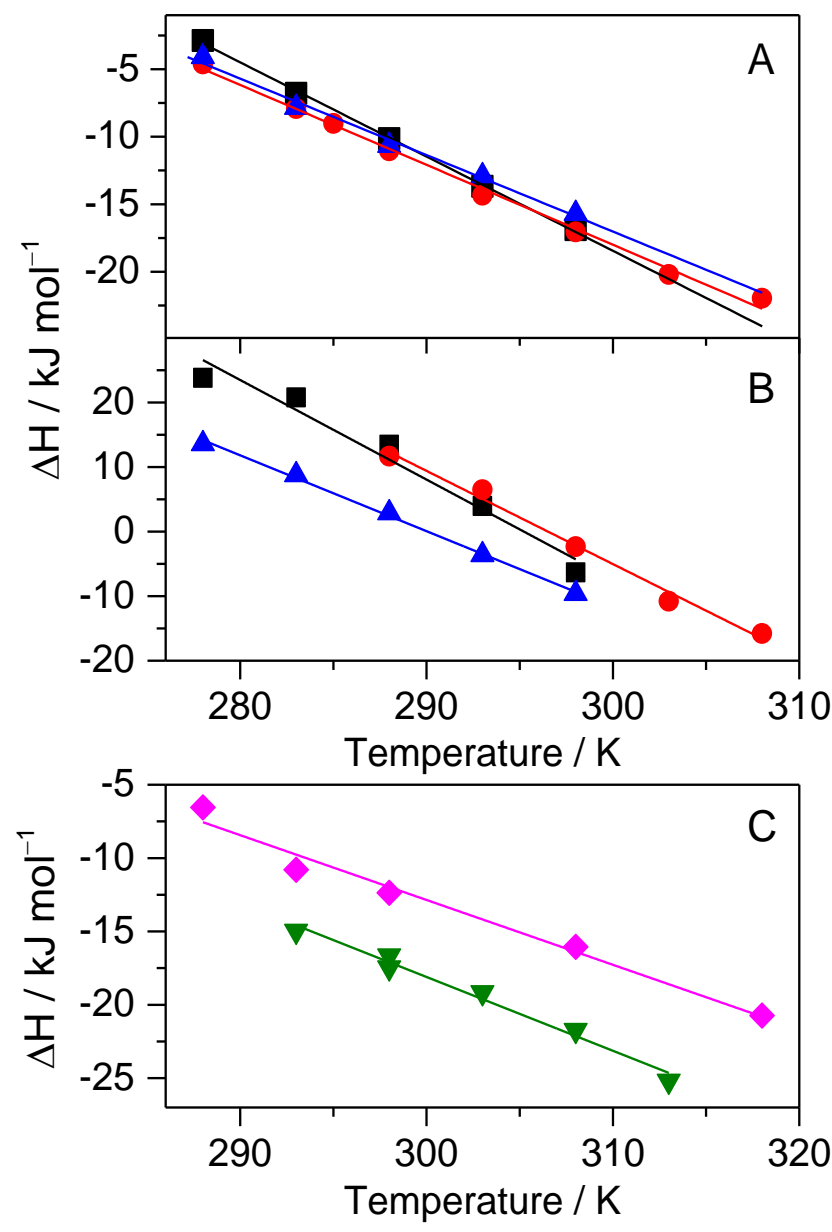

Figure 7 Temperature dependence of enthalpy change for association to supramolecular micelle (A) and NP (B) in the case of $\mathrm{C}_{14} \mathrm{TA}^{+}-\mathrm{SCX} 6(\boldsymbol{\bullet}), \mathrm{C}_{14} \mathrm{mim}^{+}-\mathrm{SCX6}^{32}$ (•), and $\mathrm{C}_{14} \mathrm{Py}^{+}-\mathrm{SCX} 6(\boldsymbol{\Delta})$ as well as (C) for NP formation of $\mathrm{C}_{14} \mathrm{Q}^{+}-\mathrm{SCX} 6(\bullet)$ and $\mathrm{C}_{14} \mathrm{MOQ}^{+}-\mathrm{SCX} 6$ $(\boldsymbol{\nabla})$ in $50 \mathrm{mM} \mathrm{NaCl}$ solution. [SCX6] $=0.1 \mathrm{mM}$

trend. The association into these NPs is highly endothermic process at low temperature (Figure 7B). The significantly more negative $\Delta C_{p}$ of NPs compared with that of SMs leads to the stabilization of NPs at elevated temperatures. The surfactants of quinolinium type are unable to assembly into SM because their NP formation is enthalpically favored even at low temperature (Figure 7C). The lowering of temperature does not destabilize these NPs because of the small negative $\Delta C_{p}$ values of their formation. When water is used as a solvent instead 
of $50 \mathrm{mM} \mathrm{NaCl}$ solution, the formation of $\mathrm{C}_{14} \mathrm{Q}^{+}-\mathrm{SCX} 6$ and $\mathrm{C}_{14} \mathrm{MOQ}^{+}-\mathrm{SCX} 6 \mathrm{NPs}$ becomes even more exothermic and $\Delta C_{p}$ remains much less negative than found for the other NPs.

Table 3 Parameters of the Temperature Dependence of Enthalpy Changes upon Association Processes in the Presence of $0.1 \mathrm{mM}$ SCX6.

\begin{tabular}{|c|c|c|c|c|c|c|}
\hline Particle & Surfactant & $\begin{array}{c}{[\mathrm{NaCl}]} \\
\mathrm{mM}\end{array}$ & $\begin{array}{c}\Delta H(298 \mathrm{~K}) \\
\mathrm{kJ} \mathrm{mol}^{-1}\end{array}$ & $\begin{array}{c}\Delta C_{p} \\
\mathrm{~kJ} \mathrm{~mol}^{-1} \mathrm{~K}^{-1}\end{array}$ & $\begin{array}{c}\text { Intercept (Int) } \\
\mathrm{kJ} \mathrm{mol}^{-1}\end{array}$ & $\begin{array}{c}T_{i e} \\
\mathrm{~K}\end{array}$ \\
\hline \multirow{5}{*}{ SM } & $\mathrm{C}_{14} \mathrm{TA}^{+} \mathrm{Br}^{-}$ & 50 & -16.9 & -0.70 & 191 & 273 \\
\hline & $\mathrm{C}_{14} \mathrm{mim}^{+} \mathrm{Br}^{-}$ & 50 & $-17.0^{\mathrm{a}}$ & $-0.59^{\mathrm{a}}$ & $159^{\mathrm{a}}$ & 269 \\
\hline & $\mathrm{C}_{14} \mathrm{Py}^{+} \mathrm{Br}^{-}$ & 50 & -15.7 & -0.57 & 154 & 270 \\
\hline & $\mathrm{C}_{14} \mathrm{Q}^{+} \mathrm{Br}^{-}$ & 50 & $\mathrm{~b}$ & $\mathrm{~b}$ & $\mathrm{~b}$ & $\mathrm{~b}$ \\
\hline & $\mathrm{C}_{14} \mathrm{MOQ}^{+} \mathrm{Br}^{-}$ & 50 & $\mathrm{~b}$ & $\mathrm{~b}$ & $\mathrm{~b}$ & $\mathrm{~b}$ \\
\hline \multirow{10}{*}{ NP } & $\mathrm{C}_{14} \mathrm{TA}^{+} \mathrm{Br}^{-}$ & 50 & -6.3 & -1.54 & 455 & 295 \\
\hline & $\mathrm{C}_{14} \mathrm{mim}^{+} \mathrm{Br}^{-}$ & 50 & $-2.3^{\mathrm{a}}$ & $-1.44^{\mathrm{a}}$ & $428^{\mathrm{a}}$ & 297 \\
\hline & $\mathrm{C}_{14} \mathrm{Py}^{+} \mathrm{Br}^{-}$ & 50 & -9.6 & -1.17 & 341 & 291 \\
\hline & $\mathrm{C}_{14} \mathrm{Q}^{+} \mathrm{Br}^{-}$ & 50 & -12.4 & -0.44 & 120 & 273 \\
\hline & $\mathrm{C}_{14} \mathrm{MOQ}^{+} \mathrm{Br}^{-}$ & 50 & -17.1 & -0.50 & 133 & 266 \\
\hline & $\mathrm{C}_{14} \mathrm{TA}^{+} \mathrm{Br}^{-}$ & 0 & -8.36 & -0.70 & 200 & 286 \\
\hline & $\mathrm{C}_{14} \mathrm{mim}^{+} \mathrm{Br}^{-}$ & 0 & $-10.8^{\mathrm{a}}$ & $-0.64^{\mathrm{a}}$ & $182^{\mathrm{a}}$ & 284 \\
\hline & $\mathrm{C}_{14} \mathrm{Py}^{+} \mathrm{Br}^{-}$ & 0 & -10.8 & -0.68 & 192 & 282 \\
\hline & $\mathrm{C}_{14} \mathrm{Q}^{+} \mathrm{Br}^{-}$ & 0 & -13.9 & -0.77 & 216 & 281 \\
\hline & $\mathrm{C}_{14} \mathrm{MOQ}^{+} \mathrm{Br}^{-}$ & 0 & -20.8 & -0.81 & 220 & 272 \\
\hline
\end{tabular}

${ }^{\mathrm{a}} \operatorname{Ref}{ }^{32-33}$. ${ }^{\mathrm{b}} \mathrm{SM}$ does not form.

3.7. Critical Aggregation Concentration of SMs. HONR solvatochromic dye (Scheme 2) was employed as a fluorescent probe for the determination of the critical aggregation concentration (cac) of SMs. The solubility and the fluorescence quantum yield of this dye are very low in water and SCX6 aqueous solution, but substantially increase upon confinement in the Stern layer of micelles. ${ }^{40}$ The surfactant concentration was progressively raised keeping 
<smiles>CCN(C)c1ccc2nc3c4cc(O)ccc4c(=O)cc-3oc2c1</smiles>

HONR

Scheme 2 The formula of 2-hydroxy-substituted nile red fluorescent probe

[surfactant]/[SCX6] molar ratio constant. Initially, the fluorescence intensity did not alter because the unaggregated compounds did not affect the solubility of HONR. Above cac, the number of SMs grew and consequently, more dye molecules could be solubilized bringing about marked fluorescence intensity enhancement. The experimental data obtained at $r=2$ and 3 component molar ratios fitted to the same trend (Figure 8). From the break in the plot,

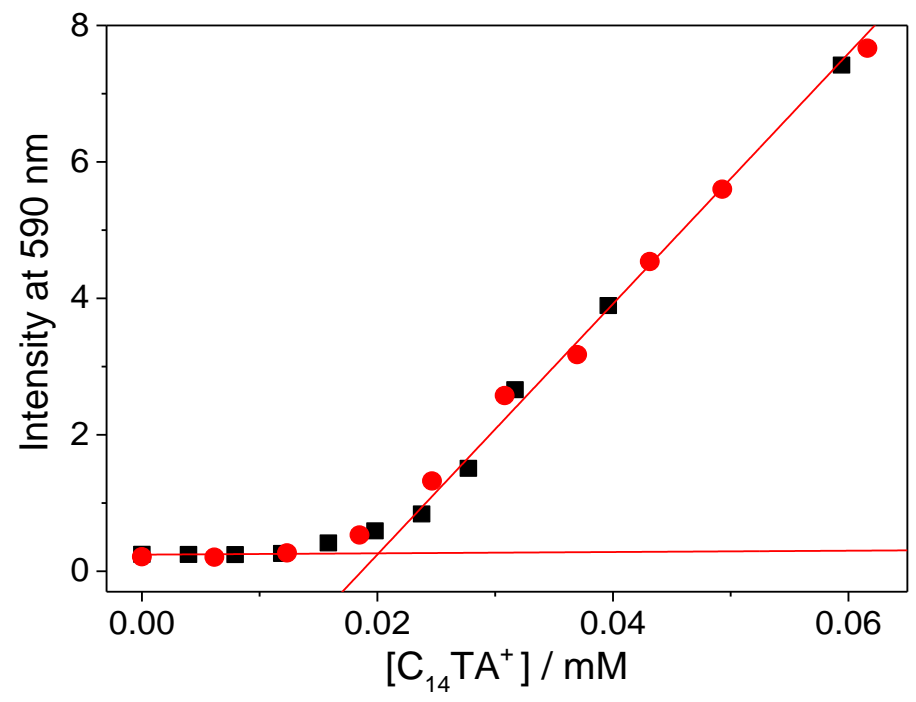

Figure 8 Variation of fluorescence intensity of the saturated HONR solution at $590 \mathrm{~nm}$ as a function of $\mathrm{C}_{14} \mathrm{TA}^{+}$concentration in $50 \mathrm{mM} \mathrm{NaCl}$ at $\mathrm{pH} 7$ and $298 \mathrm{~K} .\left[\mathrm{C}_{14} \mathrm{TA}^{+}\right] /[\mathrm{SCX} 6]=2$ $(\square)$ or $3(\bullet)$ were kept constant and excitation was performed at $510 \mathrm{~nm}$.

$0.02 \mathrm{mM}$ cac was derived for $\mathrm{C}_{14} \mathrm{TA}^{+}-\mathrm{SCX} 6 \mathrm{SMs}$ in $50 \mathrm{mM} \mathrm{NaCl}$. Analogous experiments using $r=2$ provided $0.016 \mathrm{mM}$ cac for $\mathrm{C}_{14} \mathrm{Py}^{+}-\mathrm{SCX} 6 \mathrm{SMs}$ in $50 \mathrm{mM} \mathrm{NaCl}$. These 
experiments were carried out at $283 \mathrm{~K}$ because no SM is produced around room temperature. The obtained cac values closely resemble the $0.015 \mathrm{mM}$ cac found for $\mathrm{C}_{14} \mathrm{mim}^{+}$-SCX6 SMs at $r=2$ in $50 \mathrm{mM} \mathrm{NaCl}$ at $298 \mathrm{~K}^{32}$ The slightly larger cac for $\mathrm{C}_{14} \mathrm{TA}^{+}-\mathrm{SCX} 6$ is analogous to the larger cmc of the conventional $\mathrm{C}_{14} \mathrm{TA}^{+} \mathrm{Br}^{-}$micelle compared to the other surfactant used in this study (Table 1).

\section{DISCUSSION}

Electrostatic attraction and hydrophobic interactions promote the binding of several surfactant molecules to the anionic SCX6 macrocycle. The supramolecular amphiphiles produced thereby assembly into NPs in neat water. The surfactant:SCX6 stoichiometric ratio in NPs is always close to the charge neutralization irrespective of the preparation conditions. The increase of hydrophobicity of the headgroups in the series of surfactants from $\mathrm{C}_{14} \mathrm{TA}^{+}$to $\mathrm{C}_{14} \mathrm{MOQ}^{+}$brings about substantial growth in the exothermicity of their NP formation with SCX6. The $\Delta C_{p}$ values for the NP formation vary only slightly in water (Table 3) because this quantity is primarily related to the removal of the hydration shell of the aliphatic chain upon association. ${ }^{31,35-36}$ The largest $\Delta H$ gain for the self-assembly to NPs composed of quinolinium type of surfactants probably arises from the combined effects of the hydrophobic character of quinolinium moieties, the weak repulsion among them owing to the low charge density, and their efficient $\pi-\pi$ interactions. The shorter $(2.5 \mathrm{~nm})$ spacing among the layers of the lamellar inner structure of $\mathrm{C}_{14} \mathrm{Q}^{+}-\mathrm{SCX} 6 \mathrm{NPs}$ compared to that of $\mathrm{C}_{14} \mathrm{Py}^{+}-\mathrm{SCX} 6(3.5$ $\mathrm{nm})$ and $\mathrm{C}_{14} \mathrm{mim}^{+}-\mathrm{SCX} 6(3.1 \mathrm{~nm}) \mathrm{NPs}$ is also attributable to the stronger interaction among quinolinium units.

Cac values are in the range of $0.015-0.020 \mathrm{mM}$ for the three investigated SMs and agree with those $(0.015$ and $0.012 \mathrm{mM})$ found for $\mathrm{SM}$ composed of $\mathrm{C}_{14} \mathrm{mim}^{+}$and 4sulfonatocalix[8]arene $(\mathrm{SCX} 8)^{33}$. The similar $\Delta H$ and $\Delta C_{p}$ values of all $\mathrm{SM}$ possessing 
tetradecyl chain explain the insignificant variation of cac with the alteration of the molecular structure of the constituents. The significantly lower cac of SM compared with the cmc of the corresponding conventional micelles partly stems from the smaller $\Delta H$ of the former process at all temperatures. For example, $\Delta H$ of $\mathrm{C}_{14} \mathrm{TA}^{+}$micelle formation is $-0.61 \mathrm{~kJ} \mathrm{~mol}^{-1}$ (Table 1), whereas $\Delta H$ of association to $\mathrm{SM}$ is $-16.9 \mathrm{~kJ} \mathrm{~mol}^{-1}$ in $50 \mathrm{mM} \mathrm{NaCl}$ solution at $298 \mathrm{~K}$ (Table 3). The association with SCX6 screens the electrostatic repulsion among the surfactant headgroups to a considerable extent rendering thereby assembly to SM enthalpically more favorable.

In $50 \mathrm{mM} \mathrm{NaCl}$ solutions, the variation of the headgroup of surfactants gives rise to two entirely different types of SCX6-promoted self-organizations (Scheme 3). Quinolinium

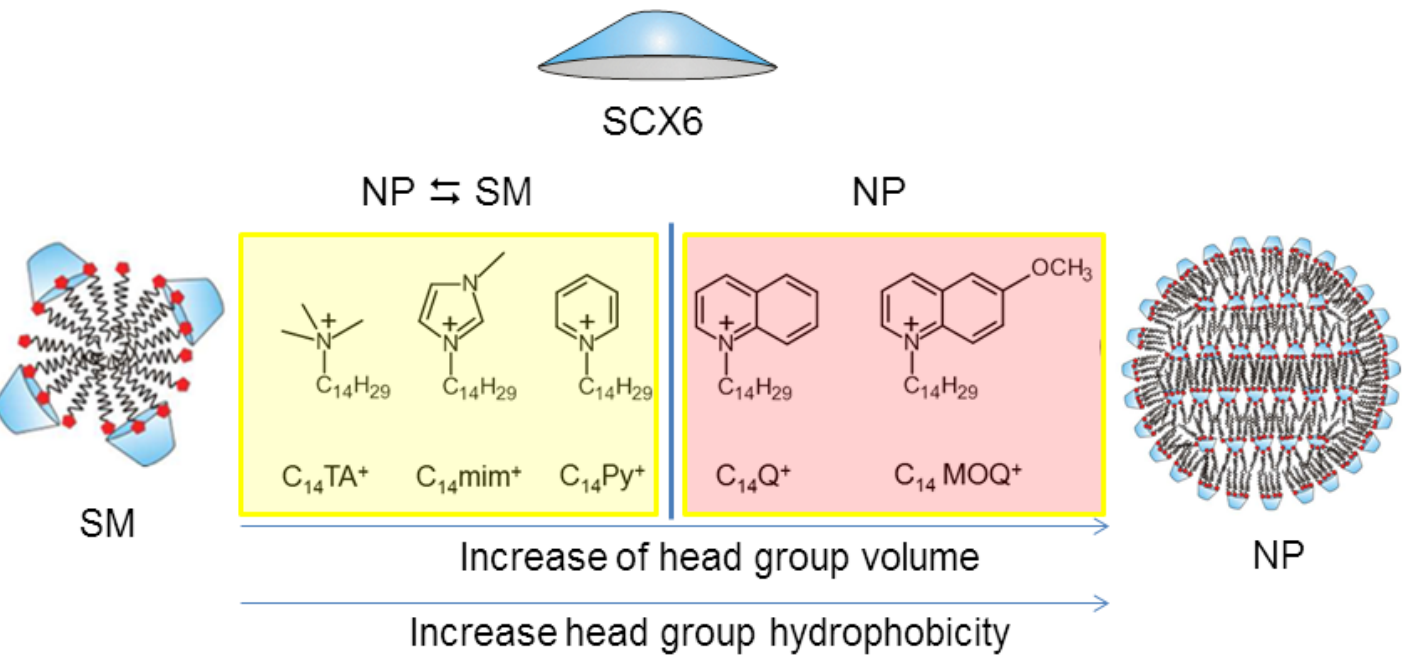

Scheme 3 Two types of self-assembly of surfactant-SCX6 complexes

surfactants produce only NPs with SCX6 under all experimental conditions because of the significant enthalpy gain in their self-organization (Figure 7C). As a result of the moderately negative $\Delta C_{p}$ in $50 \mathrm{mM} \mathrm{NaCl}$, the increase of $\Delta H$ upon cooling is not sufficient to make $\mathrm{NP}$ formation endothermic $\left(T_{i e} \leq 273 \mathrm{~K}\right)$. In contrast, surfactants containing more hydrophilic headgroups with larger charge per volume, such as trimethylammonium, methylimidazolium or pyridinium, are able to assembly with SCX6 not only into NPs but also into SM depending 
on the mixing ratio of the constituents, salt concentration and temperature. The steep temperature dependence of $\Delta H$, i.e. the significantly negative $\Delta C_{p}$ in $50 \mathrm{mM} \mathrm{NaCl}$, renders the production of these NPs enthalpically strongly unfavorable at low temperature. Under this condition, self-organization into SM occurs because this process is accompanied by enthalpy gain at all temperature. The reversible transformation between NP and SM can be induced by small temperature alteration because of the substantial difference in the $\Delta C_{p}$ of the two kinds of aggregations. The temperature intervals of NP-SM transition shifts when the headgroup of surfactants is varied because the isoenthalpic temperature $\left(T_{i e}\right)$ alters. $T_{i e}$ reaches $291 \mathrm{~K}$ for $\mathrm{C}_{14} \mathrm{Py}^{+}-\mathrm{SCX} 6 \mathrm{NPs}$, while 297 and $295 \mathrm{~K}$ are found for the least hydrophobic $\mathrm{C}_{14} \mathrm{mim}^{+}-\mathrm{SCX} 6$ and $\mathrm{C}_{14} \mathrm{TA}^{+}-\mathrm{SCX} 6$ associates.

As previously mentioned, $\Delta C_{p}$ is primarily related to the removal of the hydrate shell of the aliphatic chain upon association and shows a linear correlation with the number of hydrogen atoms of the unbranched saturated hydrocarbon chain that become unexposed to water as a result of micellization. ${ }^{37,41-42}$ Since the hydrophobic alkyl group of the surfactants was not altered in this study, no significant variation of $\Delta C_{p}$ is expected. Indeed, $\Delta C_{p}$ of SMs slightly changed with the cationic group of its surfactant component. In contrast, $\Delta C_{p}$ of NPs substantially grew with the hydrophobic character of the surfactant headgroup in the series of $\mathrm{C}_{14} \mathrm{TA}^{+}-\mathrm{SCX} 6<\mathrm{C}_{14} \mathrm{mim}^{+}-\mathrm{SCX} 6<\mathrm{C}_{14} \mathrm{Py}^{+}-\mathrm{SCX} 6<\mathrm{C}_{14} \mathrm{Q}^{+}-\mathrm{SCX} 6 \sim \mathrm{C}_{14} \mathrm{MOQ}^{+}-\mathrm{SCX} 6$. In SMs and micelles, the headgroups and a few methylene units of the alkyl tail linked to them remain partly hydrated. Hence, $\Delta C_{p}$ values of SMs and micelles are moderately negative and similar. In $50 \mathrm{mM} \mathrm{NaCl}$ solution, the $\Delta C_{p}$ values of NPs in the case of $\mathrm{C}_{14} \mathrm{TA}^{+}-\mathrm{SCX} 6$, $\mathrm{C}_{14} \mathrm{mim}^{+}-\mathrm{SCX} 6, \mathrm{C}_{14} \mathrm{Py}^{+}-\mathrm{SCX} 6$ are much more negative than $\Delta C_{p}$ of $\mathrm{SM}$ formation. This could be attributed to stronger desolvation of the constituents in the course of the association into the NP. The more hydrophilic the headgroup is the more water is released from the hydrated headgroups upon NP formation. Therefore, the charge per volume of the cationic 
surfactant correlates with $\Delta C_{p}$ of assembly with SCX6 into NPs. Table 3 demonstrates that addition of $50 \mathrm{mM} \mathrm{NaCl}$ markedly influences the thermodynamic parameters of $\mathrm{NP}$ formation. In the case of surfactants containing hydrophilic headgroup, $\left|\Delta C_{p}\right|$ and Int of SCX6-induced NP production significantly grew upon addition of $\mathrm{NaCl}$, whereas these quantities diminished in $\mathrm{NaCl}$ solution compared to those in water for quinolinium surfactants. In addition to the factors discussed in our previous paper, ${ }^{32}$ the alteration of the extent of hydration of the supramolecular surfactants may also contribute to the modification of the thermodynamics of their NP formation upon addition of $\mathrm{NaCl}$.

Another important aspect to be considered in the self-assemblies is the geometrical constraints. The variation of polar head size brings about essential differences in the SCX6induced self-assembly of $\mathrm{C}_{14} \mathrm{X}^{+}$. SM structures should correspond to the coating of surfactant micellar aggregates with SCX6 caps. This could only occur if there is a size agreement between the cross-sectional area (A) of SCX6 and the cross-sectional area of the surfactant headgroup $\left(\mathrm{a}_{0}\right)$. Indeed, A should be larger than or equal to $7 \mathrm{a}_{0}$, assuming charge neutralization in SMs. When the surfactant headgroup is too large, the geometrical matching between the SCX6 caps and surfactant headgroups $\left(\mathrm{A}<7 \mathrm{a}_{0}\right)$ is not possible and associations with large curvature at interfaces can no longer occur. Morphologies with flat curvature, as the one occurring in NPs are then the only ones favored, as illustrated in Scheme 4.
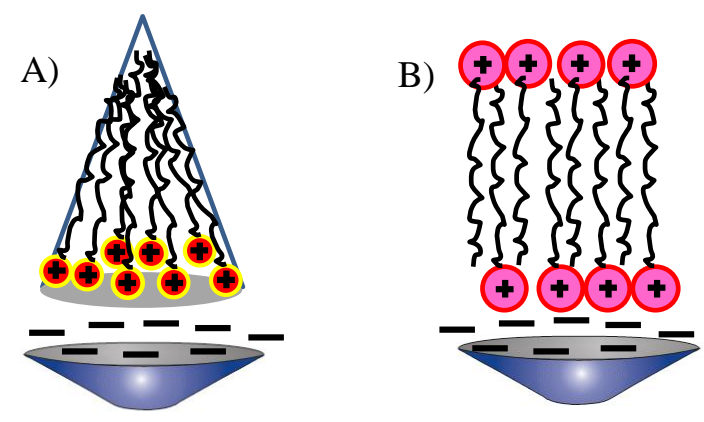

Scheme 4. Illustrated structures for the associates of SCX6 with (A) surfactants containing hydrophilic headgroup or (B) with quinolinium type of surfactants 
Calix[6]arenes have inner cavity diameters of $0.76 \mathrm{~nm},{ }^{43,44}$ which corresponds to an internal area of $\approx 0.45 \mathrm{~nm}^{2}$. In fact, A will be much larger than this value due to the six sulfonato groups which repulse each other strongly at the outer rim. The cross sectional surface areas of the headgroups can be approximated from surface tension measurements at the air water interface. The minimum area per molecule at the interface was $\sim 0.50 \mathrm{~nm}^{2}$ for $\mathrm{C}_{14} \mathrm{TA}^{+}, 45$ $\mathrm{C}_{14} \mathrm{mim}^{+},{ }^{46}$ and $\mathrm{C}_{14} \mathrm{Py}^{+}, 47$ and larger values $\left(\sim 0.80-0.90 \mathrm{~nm}^{2}\right.$ ) was reported for the two quinolinium surfactants. ${ }^{47}$ Going from the hydrophilic surfactants to the hydrophobic ones, there is a more than $50 \% \mathrm{a}_{0}$ increase (from 0.50 to $0.85 \mathrm{~nm}^{2}$ ). This brings about a change in the preferred morphologies of the aggregates ( $\mathrm{SM}$ and NP for the surfactants possessing hydrophilic cation moiety to only NP for the surfactants with hydrophobic headgroup).

\section{CONCLUSION}

SCXn-promoted NP formation seems to be a general phenomenon for cationic surfactants. We have already shown that the interaction of $\mathrm{C}_{14} \mathrm{mim}^{+}$cations and sulfonatocalix[n]arenes of various ring size $(n=4,6$, and 8$)$ resulted in NPs. ${ }^{33}$ The present results demonstrate that SCX6-induced NP production still remains even though the cationic moiety on the tetradecyl chain of surfactants is altered. Two entirely different types of SCX6-promoted selforganizations are observed depending on the headgroup of surfactants. The surfactants containing more hydrophilic headgroups with larger charge per volume are able to assembly with SCX6 not only into NPs but also into SMs depending on the mixing ratio, salt concentration and temperature. When more hydrophobic cationic moiety is linked to the aliphatic chain, only NPs are produced with SCX6 under all experimental conditions. The thermodynamic studies of the different processes pointed out the importance of the hydration of the supramolecular surfactants. The alteration of the hydration upon $\mathrm{NaCl}$ addition may contribute to the observed SM and/or NP formation. Moreover, geometrical constraints are in 
favor of NP-SM transition in the case of the headgroup possessing smaller cross-sectional area. To achieve thermoresponsive reversible $\mathrm{NP}-\mathrm{SM}$ interconversion in a narrow temperature range, the application of SCX6 and hydrophilic surfactant are the most advantageous in the presence of high salt amount.

\section{Supporting Information}

The Supporting Information is available free of charge on the ACS Publications website at DOI: Synthesis of $\mathrm{C}_{14} \mathrm{Q}^{+} \mathrm{Br}^{-}$and $\mathrm{C}_{14} \mathrm{MOQ}^{+} \mathrm{Br}^{-}$; results of quantum chemical calculations; the critical micelle concentration of $\mathrm{C}_{14} \mathrm{TA}^{+} \mathrm{Br}^{-}, \mathrm{C}_{14} \mathrm{Py}^{+} \mathrm{Br}^{-}, \mathrm{C}_{14} \mathrm{mim}^{+} \mathrm{Br}^{-}, \mathrm{C}_{14} \mathrm{Q}^{+} \mathrm{Br}^{-}$, and $\mathrm{C}_{14} \mathrm{MOQ}^{+} \mathrm{Br}^{-}$in $50 \mathrm{mM} \mathrm{NaCl}$ aqueous solution at various temperatures; variation of the mean diameter of nanoparticles as a function of $\left[\mathrm{C}_{14} \mathrm{TA}^{+} \mathrm{Br}^{-}\right] /[\mathrm{SCX} 6]$ mixing ratio at 5 min, 90 min, and 1 day after mixing the component solutions; variation of the mean nanoparticle diameter with $\left[\mathrm{C}_{14} \mathrm{Q}^{+} \mathrm{Br}^{-}\right] /[\mathrm{SCX} 6]$ and $\left[\mathrm{C}_{14} \mathrm{MOQ}^{+} \mathrm{Br}^{-}\right] /[\mathrm{SCX} 6]$ mixing ratios in $5 \mathrm{~min}, 1 \mathrm{~h}$, $3.5 \mathrm{~h}, 7 \mathrm{~h}$, and $24 \mathrm{~h}$ after the preparation at $298 \mathrm{~K}$; representative number distribution for NPs at $293 \mathrm{~K}$ and $\mathrm{SMs}$ at $283 \mathrm{~K}$ for $\mathrm{C}_{14} \mathrm{TA}^{+}-\mathrm{SCX} 6$ at $\mathrm{r}=4$ in $15 \mathrm{mM} \mathrm{NaCl}$ solution; results of ITC measurements at 283,293 , and $298 \mathrm{~K}$ in $50 \mathrm{mM} \mathrm{NaCl}$ solutions after correction with dilution heat in the titration of $0.1 \mathrm{mM}$ SCX6 solution with $3.0 \mathrm{mM} \mathrm{C}_{14} \mathrm{Py}^{+} \mathrm{Br}^{-}$at $\mathrm{pH} 7$.

\section{ACKNOWLEDGMENT}

This work was partly supported by the BIONANO GINOP-2.3.2-15-2016-00017 project and the National Research, Development and Innovation Office (NKFIH, Grant K123995). The Hungarian authors are grateful for the support. 


\section{References}

(1) Buckingham, S. A.; Garvey, C. J.; Warr, G. G. Effect of Headgroup Size on Micellization and Phase-Behavior in Quaternary Ammonium Surfactant Systems. J. Phys. Chem. 1993, 97, 10236-10244.

(2) Kamboj, R.; Bharmoria, P.; Chauhan, V.; Singh, G.; Kumar, A.; Singh, S.; Kang, T. S. Effect of Cationic Head Group on Micellization Behavior of New Amide-Functionalized Surface Active Ionic Liquids. Phys. Chem. Chem. Phys. 2014, 16, 26040-26050.

(3) Xing, H.; Yan, P.; Zhao, K. S.; Xiao, J. X. Effect of Headgroup Size on the Thermodynamic Properties of Micellization of Dodecyltrialkylammonium Bromides. $J$. Chem. Eng. Data 2011, 56, 865-873.

(4) Di Michele, A.; Brinchi, L.; Di Profio, P.; Germani, R.; Savelli, G.; Onori, G. Effect of Head Group Size, Temperature and Counterion Specificity on Cationic Micelles. J. Colloid Interface Sci. 2011, 358, 160-166.

(5) Okano, L. T.; Quina, F. H.; El Seoud, O. A. Fluorescence and Light-Scattering Studies of the Aggregation of Cationic Surfactants in Aqueous Solution: Effects of Headgroup Structure. Langmuir 2000, 16, 3119-3123.

(6) Singh, T.; Kumar, A. Aggregation Behavior of Ionic Liquids in Aqueous Solutions: Effect of Alkyl Chain Length, Cations, and Anions. J. Phys. Chem. B 2007, 111, 7843-7851.

(7) Zhang, X.; Wang, C. Supramolecular Amphiphiles. Chem. Soc. Rev. 2011, 40, 94101.

(8) Kang, Y.; Liu, K.; Zhang, X. Supra-Amphiphiles: A New Bridge between Colloidal Science and Supramolecular Chemistry. Langmuir 2014, 30, 5989-6001.

(9) Wang, C.; Wang, Z.; Zhang, X. Amphiphilic Building Blocks for Self-Assembly: From Amphiphiles to Supra-Amphiphiles. Acc. Chem. Res. 2012, 45, 608-618. 
(10) Yu, G.; Jie, K.; Huang, F. Supramolecular Amphiphiles Based on Host-Guest Molecular Recognition Motifs. Chem. Rev. 2015, 115, 7240-7303.

(11) Wang, J.; Wang, X.; Yang, F.; Shen, H.; You, Y. Z.; Wu, D. C. Effect of Topological Structures on the Self-Assembly Behavior of Supramolecular Amphiphiles. Langmuir 2015, $31,13834-13841$.

(12) Chen, Y.; Rui, L. L.; Liu, L. C.; Zhang, W. A. Redox-Responsive Supramolecular Amphiphiles Based on a Pillar[5]arene for Enhanced Photodynamic Therapy. Polym. Chem. 2016, 7, 3268-3276.

(13) Guo, D.-S.; Wang, K.; Liu, Y. Selective Binding Behaviors of $p$-Sulfonatocalixarenes in Aqueous Solution. J. Incl. Phenom. Macrocycl. Chem. 2008, 62, 1-21.

(14) Guo, D.-S.; Wang, K.; Wang, Y.-X.; Liu, Y. Cholinesterase-Responsive Supramolecular Vesicle. J. Am. Chem. Soc. 2012, 134, 10244-10250.

(15) Peng, S.; Gao, J.; Liu, Y.; Guo, D.-S. Facile Fabrication of Cross-Linked Vesicle via "Surface Clicking" of Calixarene-Based Supra-Amphiphiles. Chem. Commun. 2015, 51, 16557-16560.

(16) Wang, K.; Guo, D.-S.; Zhao, M.-Y.; Liu, Y. A Supramolecular Vesicle Based on the Complexation of $p$-Sulfonatocalixarene with Protamine and Its Trypsin-Triggered Controllable-Release Properties. Chem. Eur. J. 2016, 22, 1475-1483.

(17) Francisco, V.; Basilio, N.; Garcia-Rio, L.; Leis, J. R.; Marques, E. F.; VazquezVazquez, C. Novel Catanionic Vesicles from Calixarene and Single-Chain Surfactant. Chem. Commun. 2010, 46, 6551-6553.

(18) Wang, K.; Guo, D. S.; Liu, Y. Temperature-Controlled Supramolecular Vesicles Modulated by $p$-Sulfonatocalix[5]arene with Pyrene. Chem. Eur. J. 2010, 16, 8006-8011. 
(19) Wang, K.; Guo, D.-S.; Wang, X.; Liu, Y. Multistimuli Responsive Supramolecular Vesicles Based on the Recognition of $p$-Sulfonatocalixarene and Its Controllable Release of Doxorubicin. ACS Nano 2011, 5, 2880-2894.

(20) Wang, Y.-X.; Zhang, Y.-M.; Liu, Y. Photolysis of an Amphiphilic Assembly by Calixarene-Induced Aggregation. J. Am. Chem. Soc. 2015, 137, 4543-4549.

(21) Peng, S.; Wang, K.; Guo, D.-S.; Liu, Y. Supramolecular Polymeric Vesicles Formed by $p$-Sulfonatocalix[4]arene and Chitosan with Multistimuli Responses. Soft Matter 2015, $11,290-296$.

(22) Harangozó, J. G.; Wintgens, V.; Miskolczy, Z.; Amiel, C.; Biczók, L. Nanoparticle Formation of Chitosan Induced by 4-Sulfonatocalixarenes: Utilization for Alkaloid Encapsulation. Colloid. Polym. Sci. 2016, 294, 1807-1814.

(23) Basilio, N.; Martín-Pastor, M.; García-Río, L. Insights into the Structure of the Supramolecular Amphiphile Formed by a Sulfonated Calix[6]arene and Alkyltrimethylammonium Surfactants. Langmuir 2012, 28, 6561-6568.

(24) Basilio, N.; Garcia-Rio, L. Sulfonated Calix[6]arene Host-Guest Complexes Induce Surfactant Self-Assembly. Chem. Eur. J. 2009, 15, 9315-9319.

(25) Basilio, N.; Gómez, B.; Garcia-Rio, L.; Francisco, V. Using Calixarenes to Model Polyelectrolyte Surfactant Nucleation Sites. Chem. Eur. J. 2013, 19, 4570-4576.

(26) Xu, Z.; Peng, S.; Wang, Y.-Y.; Zhang, J.-K.; Lazar, A. I.; Guo, D.-S. Broad-Spectrum Tunable Photoluminescent Nanomaterials Constructed from a Modular Light-Harvesting Platform Based on Macrocyclic Amphiphiles. Adv. Mater. 2016, 28, 7666-7671.

(27) Geng, W.-C.; Liu, Y.-C.; Wang, Y.-Y.; Xu, Z.; Zheng, Z.; Yang, C.-B.; Guo, D.-S. A Self-Assembled White-Light-Emitting System in Aqueous Medium Based on a Macrocyclic Amphiphile. Chem. Commun. 2017, 53, 392-395. 
(28) Xu, Z.; Gonzalez-Abradelo, D.; Li, J.; Strassert, C. A.; Ravoo, B. J.; Guo, D.-S. Supramolecular Color-Tunable Photoluminescent Materials Based on a Chromophore Cascade as Security Inks with Dual Encryption. Materials Chemistry Frontiers 2017.

(29) Yu, G.; Ma, Y.; Han, C.; Yao, Y.; Tang, G.; Mao, Z.; Gao, C.; Huang, F. A SugarFunctionalized Amphiphilic Pillar[5]arene: Synthesis, Self-Assembly in Water, and Application in Bacterial Cell Agglutination. J. Am. Chem. Soc. 2013, 135, 10310-10313.

(30) Yao, Y.; Xue, M.; Chen, J.; Zhang, M.; Huang, F. An Amphiphilic Pillar[5]arene: Synthesis, Controllable Self-Assembly in Water, and Application in Calcein Release and TNT Adsorption. J. Am. Chem. Soc. 2012, 134, 15712-15715.

(31) Jie, K.; Zhou, Y.; Yao, Y.; Shi, B.; Huang, F. CO 2 -Responsive Pillar[5]arene-Based Molecular Recognition in Water: Establishment and Application in Gas-Controlled SelfAssembly and Release. J. Am. Chem. Soc. 2015, 137, 10472-10475.

(32) Wintgens, V.; Miskolczy, Z.; Guigner, J. M.; Amiel, C.; Harangozó, J. G.; Biczók, L. Reversible Nanoparticle-Micelle Transformation of Ionic Liquid-Sulfonatocalix[6]arene Aggregates. Langmuir 2015, 31, 6655-6662.

(33) Harangozó, J. G.; Wintgens, V.; Miskolczy, Z.; Guigner, J.-M.; Amiel, C.; Biczók, L. Effect of Macrocycle Size on the Self-Assembly of Methylimidazolium Surfactant with Sulfonatocalix[n]arenes. Langmuir 2016, 32, 10651-10658.

(34) Wintgens, V.; Le Coeur, C.; Amiel, C.; Guigner, J. M.; Harangozó, J. G.; Miskolczy, Z.; Biczók, L. 4-Sulfonatocalix[6]arene-Induced Aggregation of Ionic Liquids. Langmuir 2013, 29, 7682-7688.

(35) Marek, J.; Stodulka, P.; Cabal, J.; Soukup, O.; Pohanka, M.; Korabecny, J.; Musilek, K.; Kuca, K. Preparation of the Pyridinium Salts Differing in the Length of the N-Alkyl Substituent. Molecules 2010, 15, 1967. 
(36) Galgano, P. D.; El Seoud, O. A. Surface Active Ionic Liquids: Study of the Micellar Properties of 1-(1-Alkyl)-3-Methylimidazolium Chlorides and Comparison with Structurally Related Surfactants. J. Colloid Interface Sci. 2011, 361, 186-194.

(37) Paula, S.; Sues, W.; Tuchtenhagen, J.; Blume, A. Thermodynamics of Micelle Formation as a Function of Temperature: A High Sensitivity Titration Calorimetry Study. $J$. Phys. Chem. 1995, 99, 11742-11751.

(38) Bashford, M. T.; Woolley, E. M. Enthalpies of Dilution of Aqueous Decyl-, Dodecyl, Tetradecyl-, and Hexadecyltrimethylammonium Bromides at 10, 25, 40, and 55.Degree.C. J. Phys. Chem. 1985, 89, 3173-3179.

(39) Suga, K.; Ohzono, T.; Negishi, M.; Deuchi, K.; Morita, Y. Effect of Various Cations on the Acidity of p-Sulfonatocalixarenes. Supramol. Sci. 1998, 5, 9-14.

(40) Nagy, K.; Göktürk, S.; Biczók, L. Effect of Microenvironment on the Fluorescence of 2-Hydroxy-Substituted Nile Red Dye: A New Fluorescent Probe for the Study of Micelles. J. Phys. Chem. A 2003, 107, 8784-8790.

(41) Gill, S. J.; Wadsö, I. An Equation of State Describing Hydrophobic Interactions. Proc. Natl. Acad. Sci. USA 1976, 73, 2955-2958.

(42) Kresheck, G. C.; Hargraves, W. A. Thermometric Titration Studies of the Effect of Head Group, Chain Length, Solvent, and Temperature on the Thermodynamics of Micelle Formation. J. Colloid Interface Sci. 1974, 48, 481-493.

(43) Mokhtari, B.; Pourabdollah, K. Applications of Calixarene Nano-Baskets in Pharmacology. J. Incl. Phenom. Macrocycl. Chem. 2012, 73, 1-15.

(44) Ma, X.; Zhao, Y. Biomedical Applications of Supramolecular Systems Based on Host-Guest Interactions. Chem. Rev. 2015, 115, 7794-7839.

(45) Adamczyk, Z.; Para, G.; Warszyński, P. Influence of Ionic Strength on Surface Tension of Cetyltrimethylammonium Bromide. Langmuir 1999, 15, 8383-8387. 
(46) Ao, M.; Kim, D. Aggregation Behavior of Aqueous Solutions of 1-Dodecyl-3Methylimidazolium Salts with Different Halide Anions. J. Chem. Eng. Data 2013, 58, 15291534.

(47) Quagliotto, P.; Barbero, N.; Barolo, C.; Artuso, E.; Compari, C.; Fisicaro, E.; Viscardi, G. Synthesis and Properties of Cationic Surfactants with Tuned Hydrophylicity. $J$. Colloid Interface Sci. 2009, 340, 269-275. 
Table of contents graphic

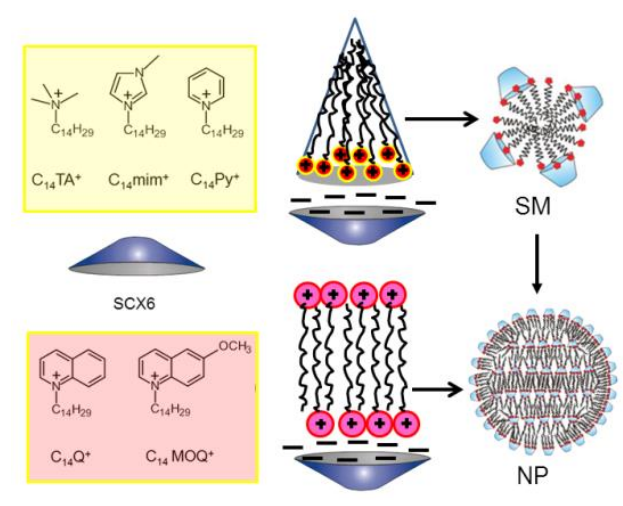

